\title{
Tracheal Length in Adult Human: The Results of 100 Autopsies
}

\author{
Longitud de la Tráquea en Humanos Adultos: Los Resultados de 100 Autopsias
}

\author{
Ugur Cinar*; Semih Halezeroglu**; Erdal Okur**; Mehmet Akif Inanici**** \& Semra Kayaoglu ${ }^{* * * * *}$
}

CINAR, U.; HALEZEROGLU, S.; OKUR, E.; INANICI, M. A. \& KAYAOGLU, S. Tracheal length in adult human: The results of 100 autopsies. Int. J. Morphol., 34(1):232-236, 2016.

SUMMARY: The purpose of this study was to investigate the average tracheal length and number of the tracheal cartilages in Turkish people, with emphasis on the relationships to body height and sex. A hundred fresh human cadaver tracheas were harvested from 75 males and 25 females. Age, sex and body height of cadavers were recorded. All the neck and intrathoracic structures were removed. The tracheal length was measured between the subcricoid level to the carina in resting and maximally stretched positions. Average tracheal length and number of the tracheal cartilages were compared in different body height groups in both sexes. We found that average body height was $160 \pm 6.4 \mathrm{~cm}$ and average tracheal length in resting position was $8.5 \pm 1 \mathrm{~cm}$ (range $6.5-11 \mathrm{~cm}$ ) in females and average body height was $168.6 \pm 5.6 \mathrm{~cm}$, average tracheal length was $8.7 \pm 1.1 \mathrm{~cm}$ (range 7-11.6 cm) in males, average number of tracheal cartilages was 13.6 \pm 1.7 (range 10-16) in females and 13.3 \pm 1.6 (range 10-19) in males and average number of the tracheal cartilages per centimeter was $1.6 \pm 0.2$ in female and $1.5 \pm 0.2$ in male cadavers in resting position. Average tracheal length in male group was found to be significantly different in cadavers with body height equal or taller than $170 \mathrm{~cm}$ in comparison to cadavers with body height shorter than $170 \mathrm{~cm}(\mathrm{p}$ $<0.05)$. This study revealed that the average tracheal length in Turkish people is shorter than the reported length in literature. It is worth commenting that there is a considerable difference between the different races with regard to tracheal length. Tracheal length may vary with body height.

KEY WORDS: Trachea; Tracheal length; Body height; Anatomy; Cadaver.

\section{INTRODUCTION}

Tracheal length in human has been investigated by only a few studies. Grillo spent a tremendous effort to document the anatomical characteristics of this primary airway. Grillo et al. (1964) and Grillo (2000) reported that the adult human trachea averages $11.8 \mathrm{~cm}$ in length (range $10-13 \mathrm{~cm}$ ) and that there are 18 to 22 cartilaginous rings within this length. The 2008 edition of Gray's Anatomy states that the trachea is $10-11 \mathrm{~cm}$ long, is composed of 16-20 tracheal cartilages (Standring et al., 2005). Kamel et al. (2009) investigated in vivo and in vitro morphometry of the human trachea and showed that the mean tracheal length was $10.5 \pm 0.9 \mathrm{~cm}$ in males, and $9.8 \pm 0.8 \mathrm{~cm}$ in females.

As tracheal surgery is infrequent, all thoracic surgeons cannot be expected to have extensive experience in the trachea. The incidence of post-intubation tracheal stenosis has been decreased with the recognition of its etiology; however, it remains the most common indication for tracheal surgery (Wain, 2009). For a patient with the stenosis after extubation, surgical approaches such as primary resection and anastomosis or various methods of tracheoplasty should be selected. Eventually, the most practical and commonly used pathway to deal with the surgical trachea disorders remains to follow guidelines given by experienced colleagues. However, unavoidably, the lack of adequate experience may bring some unforeseeable problems. For instance, a surgeon learns that there is a certain amount of trachea that can safely be resected. If this length is applied to all patients without regard for body height or sex, some operative or post-operative tragedy may occur. On the other hand, malpositioning of the endotracheal tube within the airway leads to serious complications such as endobronchial intubation, vocal cord paralysis and accidental extubation. Prediction of the correct tracheal length is important for anesthesiologists.

* Department of Otolaryngology, Acibadem International Hospital, Istanbul, Turkey.

** Department of Thoracic Surgery, Faculty of Medicine, Acibadem University, Istanbul, Turkey.

*** Department of Forensic Medicine, Faculty of Medicine, Marmara University, Istanbul, Turkey.

***** Family Medicine Center, Istanbul, Turkey. 
In this study, length of the trachea and number of the tracheal cartilages in Turkish people were investigated, with emphasis on the relationships to body height and sex.

\section{MATERIAL AND METHOD}

A study protocol designed to investigate the tracheal length and number of the cartilaginous rings of the trachea in 100 cadavers was submitted to the Institute of Forensic Medicine. The study was performed between May 2013 and May 2014.

A hundred fresh human cadaver tracheas were harvested from 75 men and 25 women, with a range of 18 82 years. Legal and ethical considerations were consistent with the rules of the Marmara University Research Ethics Committee. As the post-mortem changes would cause differences in measurements, those who died within the last 24 hours were included in the study. No cadaver had a history of neck injury. Forensic medicine specialist performed all of the autopsies. Body height was measured and recorded together with the sex and age of the cadaver. Then, chest was opened by sternotomy, and the structures in the neck and thorax were removed totally. The number of tracheal rings were counted in the median sagittal plane. Trachea was measured between the inferior margins of cricoid to the tracheal bifurcation in two different positions:

a) Relaxed position: The sizes were measured when there was no stretching effect to the trachea which was attached with the intrathoracic organs. In this position, the stretching effect of the intrathoracic structures (bronchi, lungs) in a standing body was eliminated.

b) Maximally stretched position: Trachea was dissected and completely separated from other organs and structures. Then, the lower end of the trachea was attached to the table and the upper end stretched maximally.

Cadavers were divided into two groups according to body height such as: shorter than $160 \mathrm{~cm}$ and equal or taller than $160 \mathrm{~cm}$ in female, and body height shorter than $170 \mathrm{~cm}$ and equal or taller $170 \mathrm{~cm}$ in male. Length of the trachea, number of the tracheal cartilages, and number of the tracheal cartilages per centimeter were calculated in these groups.

Data of the study was evaluated using descriptive statistical methods (mean, standard deviation) as well as Student's $t$ test and Mann Whitney U test. Probability values less than 0.05 were considered statistically significant. Statistical analyses were performed using SPSS (Chicago, III) statistical software, version 10.0 running on an IBMcompatible personal computer.

\section{RESULTS}

Age and sex distribution, body height, length of the trachea, number of the cartilaginous rings per centimetre of the trachea in resting and maximally stretched positions and the number of the tracheal cartilages are represented in Table I. Distribution of length of the tracheal cartilages and length of the trachea in resting and maximally stretched positions

Table I. The average tracheal length and number of the tracheal cartilages and its relationships to body height, age and sex in 100 cadavers

\begin{tabular}{|c|c|c|c|c|}
\hline Findings & $\begin{array}{l}\text { Female } \\
(n=25)\end{array}$ & $\begin{array}{c}\text { Male } \\
(n=75)\end{array}$ & p value & $\begin{array}{c}\text { Average } \\
(n=100)\end{array}$ \\
\hline Mean age & $37.7 \pm 18.4$ & $42.2 \pm 14.6$ & $>0.05$ & $41.1 \pm 15.7$ \\
\hline Average body height $(\mathrm{cm})$ & $160.4 \pm 6.4$ & $168.6 \pm 5.6$ & $<0.01^{*}$ & $166.5 \pm 6.8$ \\
\hline $\begin{array}{l}\text { Average length of the trachea } \\
\text { (resting position, } \mathrm{cm} \text { ) }\end{array}$ & $8.5 \pm 1.0$ & $8.7 \pm 1.1$ & $>0.05$ & $8.6 \pm 1.1$ \\
\hline $\begin{array}{l}\text { Average length of the trachea } \\
\text { (maximally stretched, } \mathrm{cm} \text { ) }\end{array}$ & $10.2 \pm 1.0$ & $10.5 \pm 1.2$ & $>0.05$ & $10.4 \pm 1.1$ \\
\hline Lengthening capacity of the trachea (\%) & 20 & 20 & --- & 20 \\
\hline $\begin{array}{l}\text { Difference between the average length of } \\
\text { the trachea in two different positions }(\mathrm{cm})\end{array}$ & $1.7 \pm 0.8$ & $1.8 \pm 0.5$ & $>0.05$ & $1.8 \pm 0.8$ \\
\hline Average number of the tracheal cartilages & $13.6 \pm 1.7$ & $13.3 \pm 1.6$ & $>0.05$ & $13.4 \pm 1.6$ \\
\hline $\begin{array}{l}\text { Average number of the tracheal cartilages } \\
\text { per centimetre (in resting position) }\end{array}$ & $1.6 \pm 0.2$ & $1.5 \pm 0.2$ & $>0.05$ & $1.5 \pm 0.2$ \\
\hline $\begin{array}{l}\text { Average number of the tracheal cartilages } \\
\text { per centimetre (in stretched position) }\end{array}$ & $1.3 \pm 0.1$ & $1.2 \pm 0.1$ & $<0.05^{*}$ & $1.2 \pm 0.1$ \\
\hline
\end{tabular}

$*=$ statistically significant. 
were found similar in both sexes. The average length of the trachea and the number of the tracheal cartilages were not found to be statistically different in female cadavers taller than $160 \mathrm{~cm}$ when compared to those shorter than $160 \mathrm{~cm}$. However, in male cadaver group, the average tracheal length was found significantly longer in cadavers taller than 170 $\mathrm{cm}$ when compared to cadavers shorter than $170 \mathrm{~cm}(\mathrm{p}<0.05)$ (Table II). The difference between the average lengths of the trachea in two different positions was found to be $1.8 \pm 0.8$ $\mathrm{cm}$. Comparison of the length of the trachea in resting and maximally stretched positions revealed that trachea has 20 $\%$ lengthening capacity (Figs. 1 and 2).

Table II. Comparison of the average length of the trachea and the number of the tracheal cartilages in both sexes according to body height.

\begin{tabular}{|c|c|c|c|c|c|c|}
\hline \multirow{3}{*}{ Findings (averages) } & \multicolumn{6}{|c|}{ Body height (cm) } \\
\hline & \multicolumn{3}{|c|}{ Female $(n=25)$} & \multicolumn{3}{|c|}{ Male $(n=75)$} \\
\hline & $\begin{array}{c}<160 \\
(n=12)\end{array}$ & $\begin{array}{c}\geq 160 \\
(n=13)\end{array}$ & p value & $\begin{array}{c}<170 \\
(n=38)\end{array}$ & $\begin{array}{c}\geq 170 \\
(n=37)\end{array}$ & $\mathrm{p}$ value \\
\hline Body height & $155.3 \pm 2.3$ & $165.0 \pm 5.4$ & $<0.01 *$ & $164.3 \pm 4.0$ & $173.0 \pm 3.1$ & $<0.01 *$ \\
\hline Age & $39.5 \pm 20.7$ & $36.1 \pm 16.8$ & $>0.05$ & $41.5 \pm 15.6$ & $42.9 \pm 13.7$ & $>0.05$ \\
\hline Length of the trachea (resting & $8.5 \pm 1.2$ & $8.5 \pm 0.9$ & $>0.05$ & $8.4 \pm 1.1$ & $9.0 \pm 1.0$ & $<0.05^{*}$ \\
\hline $\begin{array}{l}\text { Length of the trachea } \\
\text { (maximally stretched position, cm) }\end{array}$ & $10.2 \pm 1.2$ & $10.2 \pm 0.8$ & $>0.05$ & $10.4 \pm 1.2$ & $10.6 \pm 1.1$ & $>0.05$ \\
\hline Number of the cartilages & $13.4 \pm 1.6$ & $13.8 \pm 1.8$ & $>0.05$ & $13.3 \pm 1.7$ & $13.4 \pm 1.6$ & $>0.05$ \\
\hline
\end{tabular}

*= statistically significant.

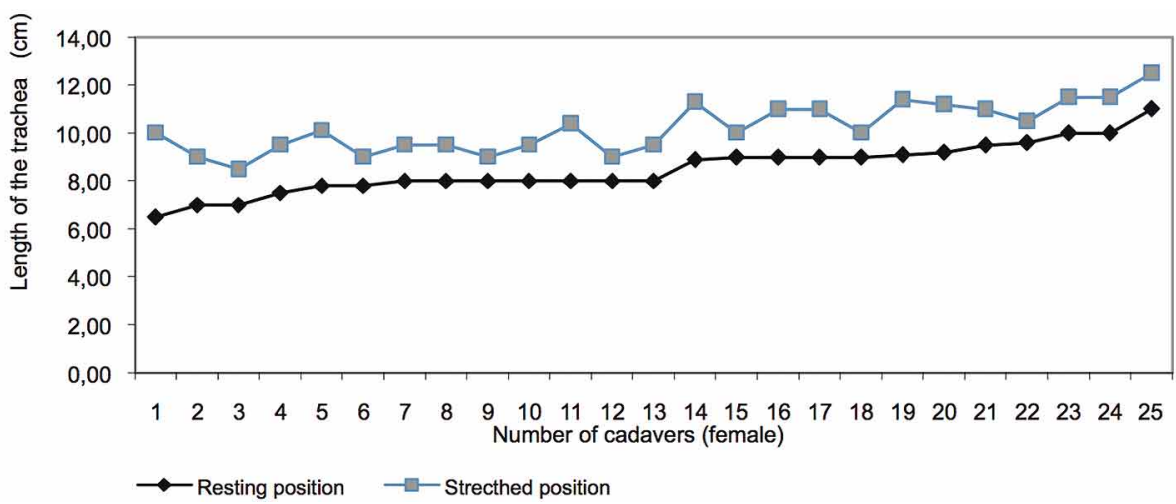

Fig. 1. Case distribution according to the length of the trachea in two different positions in female group.

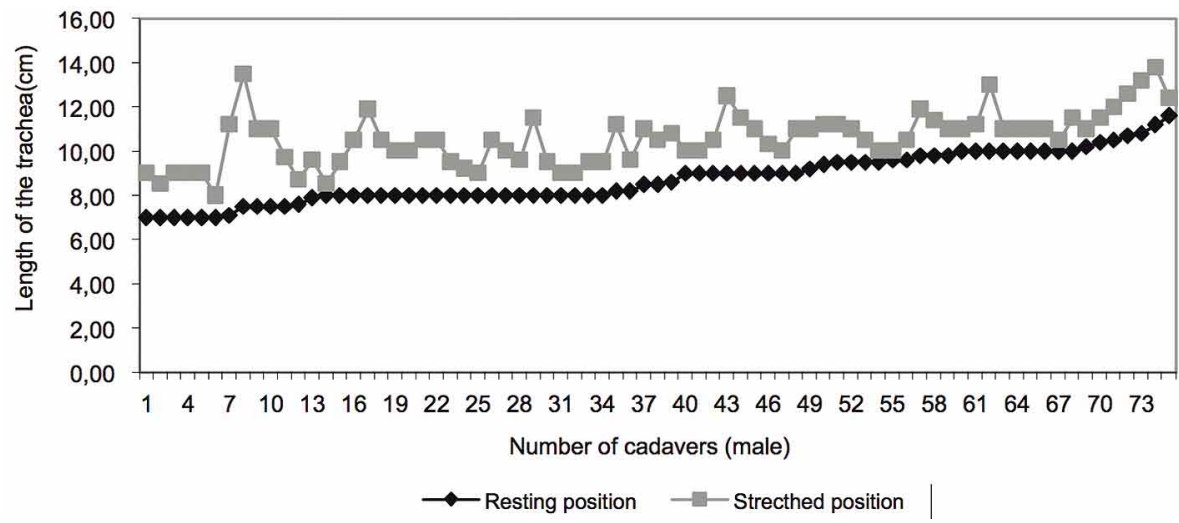

Fig. 2. Case distribution according to the length of the trachea in two different positions in male group. 


\section{DISCUSSION}

The trachea is one of the most ignored parts of the entire respiratory tract. Little attention has been devoted to this organ in ordinary anatomy textbooks. Similarly, tracheal surgery is one of the rare engagements of surgeons that only a few surgeons might have a large experience to decide the safely resectable amount of trachea in different patients. The length of trachea that may be resected safely in an individual is the most important subject in tracheal surgery. One must be aware that the stated amount of trachea that can safely be resected in human was calculated with the data obtained from people living in certain areas of the world. The principal purpose of this study was to see if there were any differences between the lengths of trachea in Turkish people and those in the literature.

Many studies which examine the length of tracheas use such methods as chest X-rays, computed tomography, flexible bronchoscopy or cadaver specimens. Previous studies have suggested that the tracheal length may be related to the body height of the patient (Eagle, 1992), sternal length (Cherng et al., 2002) and thyro-sternal length (Chong et al., 2006). Toremalm (1986) reported that there are 14 to 20 tracheal cartilages. According to Weir (1987), the trachea is about $10-11 \mathrm{~cm}$ in length and the number of cartilages in the trachea varies from 16-20. Armstrong \& Netterville (1995) reported that the length of the trachea is approximately $11 \mathrm{~cm}$ in the cadaver and it is slightly longer in the living adult. The main findings from Kamel et al. study showed that there were 14-20 tracheal cartilages in the midline, and that the tracheal length was $8-12 \mathrm{~cm}$ in vivo whereas the tracheal length was $2 \mathrm{~mm}$ less in cadaver specimens.

Pang et al. (2010) have chosen to measure the vocal cord-carina distance using a flexible bronchoscope during anesthesia and they found that the average body height was $163 \pm 8 \mathrm{~cm}$ and average vocal ford-carina distance was $11.8 \pm 1.3$ $\mathrm{cm}$ in Caucasian females, and average body height was $179 \pm 8$ $\mathrm{cm}$ and average vocal ford-carina distance was $13.6 \pm 1.4 \mathrm{~cm}$ in Caucasian adult males. Pang found that a poor correlation between the body height and the vocal fords-carina distance. In Kamel's et al. study tracheal length was measured from the inferior border of the cricoid cartilage to the carina on CT scans and these showed that in the supine position, the adult trachea was $10.5 \pm 0.9 \mathrm{~cm}$ long in males and $9.8 \pm 0.8 \mathrm{~cm}$ long in females in vivo. Munguía-Canales et al., found the average body height $161 \pm 7 \mathrm{~cm}$, tracheal length $8.6 \pm 0.5 \mathrm{~cm}$ in female cadavers and average body height $169 \pm 6 \mathrm{~cm}$, tracheal length $9.1 \pm 0.9 \mathrm{~cm}$ in male cadavers in the Mexican population. They showed that there was no significant correlation between tracheal length and body height with respect to sex.
In this study, we found that in females, the average body height was $160 \pm 6.4 \mathrm{~cm}$, average tracheal length in resting position was $8.5 \pm 1 \mathrm{~cm}$ (range $6.5-11 \mathrm{~cm}$ ). In males, the average body height was $168.6 \pm 5.6 \mathrm{~cm}$, average tracheal length in resting position was $8.7 \pm 1.1 \mathrm{~cm}$ (range $7-11.6 \mathrm{~cm}$ ). In females, the average number of tracheal cartilages was $13.6 \pm 1.7$ (range 10-16), whereas it is $13.3 \pm 1.6$ (range1019 ) in males. The average number of tracheal cartilages per centimeters was $1.6 \pm 0.2$ in female cadavers versus $1.5 \pm 0.2$ in male cadavers in resting position. Average tracheal length in male group was found to be significantly different in cadavers with body height equal or taller than $170 \mathrm{~cm}$ compared to cadavers with body height shorter than $170 \mathrm{~cm}$ $(\mathrm{p}<0.05)$. It means that tracheal length may vary with body height in men. In this study, we also found that average length of the trachea was $8.6 \mathrm{~cm}$ (range 6.5-11.6) in resting position and $10.4 \mathrm{~cm}$ (range 8-13.8) in maximal stretched position in cadavers. The difference of the average tracheal length between two different positions was found to be $1.8 \mathrm{~cm}$ which means that the length of trachea may extend up to its length $20 \%$ under maximal stretching. Average number of cartilages was found tobe 13.4 (range 10-19) and average number of the tracheal cartilages per centimeter was found to be 1.5 in resting position and 1.2 in maximally stretched position.

In conclusion, this study revealed that the average tracheal length in Turkish people is shorter than the reported lengths in the literature. We found that there is a correlation between body height and tracheal length in men. We also note the fact that there is a considerable difference between the lengths of trachea in different races. Therefore, it is suggested that, surgeons who deal with tracheal surgery pay attention to the fact that the safely resectable trachea may vary in different populations due to the difference in tracheal length. For successful results, it is best for the surgeons to individualize the planned resectional tracheal length in every patient. This individualization must include some of the patient characteristics such as age, sex and pre-existing lung disease as well as the race characteristics as documented in this study.

CINAR, U.; HALEZEROGLU, S.; OKUR, E.; INANICI, M. A. \& KAYAOGLU, S. Longitud de la tráquea en humanos adultos: Resultados de 100 autopsias. Int. J. Morphol., 34(1):232-236, 2016.

RESUMEN: El objetivo de este estudio fue investigar la longitud traqueal promedio y el número de los cartílagos traqueales en pueblo turco, con énfasis en las relaciones a la altura del cuerpo y el sexo. Cien tráqueas frescas de cadáveres humanos fueron extraidas de 75 hombres y 25 mujeres. Se registraron la edad, sexo y altura del cuerpo en cada caso. Se disecaron el cuello y las es- 
tructuras intratorácicas. La longitud de la tráquea fue medida entre el nivel subcricoides y la carina en reposo, y en posición de máximo estiramineto. Se comparó la longitud promedio traqueal y el número de los cartílagos traqueales ente grupos con diferente de la altura del cuerpo en ambos sexos. En las mujeres, la altura del cuerpo promedio fue $160 \pm 6,4 \mathrm{~cm}$ y la longitud traqueal promedio en posición de reposo 8,5 $\pm 1 \mathrm{~cm}$ (rango 6,5-11 cm). En hombres, la altura del cuerpo promedio fue $168,6 \pm 5,6 \mathrm{~cm}$ y la longitud traqueal promedio $8,7 \pm 1,1 \mathrm{~cm}$ (rango 7-11,6 cm). El número promedio de cartílagos traqueales fue $13,6 \pm 1,7$ (rango 10-16) en las mujeres y 13,3 $\pm 1,6$ (rango 10-19) en los hombres, y el número promedio de cartílagos traqueales por centímetro fue $1,6 \pm 0,2$ en mujeres y $1,5 \pm 0,2$ en los hombres, en posición de reposo. La longitud traqueal promedio en el grupo de hombres fue significativamente diferente en cadáveres con una altura del cuerpo igual o mayor que $170 \mathrm{~cm}$, en comparación con cadáveres con la altura del cuerpo menor a $170 \mathrm{~cm}(\mathrm{p}<0,05)$. Este estudio reveló que la longitud traqueal promedio en pueblo turco es menor que la longitud reportada en la literatura. Por otra parte, existe una diferencia considerable entre las diferentes razas con respecto a la longitud traqueal. La longitud traqueal puede variar con la altura del cuerpo.

PALABRAS CLAVE: Tráquea; Longitud traqueal; Altura corporal; Anatomía; Cadaver.

\section{REFERENCES}

Armstrong, W. B. \& Netterville, J. L. Anatomy of the larynx, trachea, and bronchi. Otolaryngol. Clin. North Am., 28(4):68599, 1995.

Cherng, C. H.; Wong, C. S.; Hsu, C. H. \& Ho, S. T. Airway length in adults: estimation of the optimal endotracheal tube length for orotracheal intubation. J. Clin. Anesth., 14(4):271-4, 2002.

Chong, D. Y.; Greenland, K. B.; Tan, S. T.; Irwin, M. G. \& Hung, C. T. The clinical implication of the vocal cords-carina distance in anaesthetized Chinese adults during orotracheal intubation. Br. J. Anaesth., 97(4):489-95, 2006.

Eagle, C. C. The relationship between a person's height and appropriate endotracheal tube length. Anaesth. Intensive Care, 20(2):156-60, 1992.

Grillo, H. C.; Dignan, E. F. \& Miura, T. Extensive resection and reconstruction of mediastinal trachea without prosthesis or graft: an anatomical study in man. J. Thorac. Cardiovasc. Surg., 48:741-9, 1964.

Grillo, H.C. Surgical Anatomy of the Trachea and Techniques of Resection. In: Shields, T. W.; Locicero, J. \& Ponin, R. B. (Eds.). General Thoracic Surgery. $5^{\text {th }}$ ed. Philadelphia, Lippincott Williams and Wilkins, 2000. pp.873-83.
Kamel, K. S.; Lau, G. \& Stringer, M. D. In vivo and in vitro morphometry of the human trachea. Clin. Anat., 22(5):571-9, 2009.

Munguía-Canales, D. A.; Ruiz-Flores, J.; Vargas-Mendoza, G. K.; Morales-Gómez, J.; Méndez-Ramírez, I. \& Murata C. Tracheal dimensions in the Mexican population. Cir. Cir., 79(6):50510, 2011.

Pang, G.; Edwards, M. J. \& Greenland, K. B. Vocal cords-carina distance in anaesthetised Caucasian adults and its clinical implications for tracheal intubation. Anaesth. Intensive Care, 38(6):1029-33, 2010.

Standring, S.; Ellis, H. \& Berkovitz, B. H. B. Gray's Anatomy: The Anatomical Basis of Clinical Practice. 39th ed. Edinburgh, Elsevier Churchill Livingstone, 2005. pp.1063-82.

Toremalm, N. G. Physiology (Trachea/Esophagus). In: Cummings, C. W.; Fredrickson, J. M.; Harker, L. A.; Krause, C. J. \& Schuller, D. E. (Eds.). Otolaryngology Head and Neck Surgery. St. Louis, C.V. Mosby Company, 1986. pp.2243-56.

Wain, J. C. Jr. Postintubation tracheal stenosis. Semin. Thorac. Cardiovasc. Surg., 21(3):284-9, 2009.

Weir, N. Anatomy of the Larynx and Tracheobronchial Tree. In: Kerr, A. G. (Ed.). Scott-Brown's Otolaryngology. $6^{\text {th }}$ ed. London, Butterworths, 1997.

\author{
Correspondence to: \\ Ugur Cinar, MD \\ Korkadi sok. Turizm sitesi \\ 4. Blok, No:13 Ulus \\ Istanbul 34340 \\ TURKEY
}

Phone: +90 2124684444
Fax: $\quad+902126632862$

Email: u_cinar@yahoo.com ugurcinar@ihi.com.tr

Received: 29-07-2015

Accepted: 23-12-2015 